\section{Akhmet Yarlykapov}

PhD in History, Senior researcher,

Center for Caucasus and regional security of the Institute of International Studies,

MGIMO (Moscow), itbal@mail.ru

\section{Andir-Shopai: syncretic image of gromovnik in the Nogai rite}

\section{of rainmaking}

The author analyzes the actual ethnographic material related to the rites of rainmaking among the Nogai people. The dodol rite of rainmaking, which dates back to pre-monotheistic times, is not considered by the people as a pagan tradition and is essentially an appeal to the one and only God. This rite is well within the framework of the Muslim rite, since Islam recognizes a special prayer for rain. Therefore, the participation of Muslim Ministers of worship in the Nogai rite of rainmaking is legitimate and can not be considered as a deviation from the norms of Islam. Such rites of rainmaking are typical for all the peoples of South-Eastern Europe, Eastern Slavs, the peoples of the Volga region, the Caucasus, and Central Asia.

Keywords: Andir-Shopai, calendar rites, ritual rainmaking, Ethnography Nogai, intangible heritage, dodol rituals

\title{
АНТРОПОЛОГИЯ СОВЕТСКОСТИ
}

Анна Шевцова, Иван Гринько

\section{Клятва Айболита: иконография медика в советской карикатуре}

Статья посвящена визуальным репрезентациям работников системы здравоохранения в сатире советского периода. В качестве источниковой базы была использована совет ская карикатура и частично кинематограф 1950-1980-х г2. В фокусе внимания авторов динамика сюжетов, гендерный аспект, престиж профессии, проблемы системы здравоохранения, в том числе оставшиеся «за кадром». Отдельные сюжеты анализируются в сравнении современными формами визуальной культуры (стрит-арт, мемы и т.д.), посвященными остроактуальной теме борьбы с пандемией COVID-19.

Ключевые слова: советская история, карикатура, история медицины, здравоохранение, образ врача, журнал «Крокодил», визуализация болезни, образ пациента, визиотип

«Любовъ к врачебному искусству это и есть любовъ к человечеству».

Гиппократ

«Врач должен обладать взглядом сокола, руками девушки, мудростью змеи и сердием льва.

Шевцова Анна

Александровна, доктор

исторических наук, профессор кафедры культурологии

Московского педагогического государственного университета (Москва),

ash@inbox.ru

Гринько Иван Александрович кандидат исторических наук, начальник Управления музейнотуристского развития ГАУК «МОСГОРТУР» (Москва) igrinko@mosgortur.ru

\section{Ибн Сина (Авиценна)}

Гуманитарные последствия продолжающейся пандемии COVID-19 еще предстоит оценить, однако очевидно что оценка фигуры врача в массовом сознании за последние месяцы подверглась глобальному пересмотру. Медики, сражающиеся не только с последствиями инфекции, но и с невежеством и легкомыслием своих пациентов, стали героями плакатов, стрит-арта, 
визуального сетевого фольклора. Один из ярких примеров - фреска китайского художника Дуи Ханя в часовне в печально известной провинции Хубэй - родине нулевого пациента с короновирусом. Фреска «Святые носят белое», изображающая врачей и медсестер в белоголубых костюмах химзащиты, стала данью искреннего уважения всем медикам, спасающим человеческие жизни. Потеснившие суперменов на плакатах, мемах и муралах врачи призывают соблюдать санитарно-гигиенические правила, оставаться дома, соблюдать социальную дистанцию. Подобно тому, как во время войны или катастрофы медики «теряют» специализацию, становясь просто «медициной» и спасая раненых, все сегодняшние врачи, независимо от полученной в вузе и интернатуре специальности, также мобилизованы для борьбы с пандемией. Кредит доверия людям этой героической профессии огромен, однако так было не всегда, и наша дань уважения - попытаться понять, почему.

Лелеемый в массовом сознании миф о бесплатной, но неизменно высококачественной советской медицине для всех и каждого не выдерживает столкновения даже с отлакированными цензурой источниками - caтирической печатью и кинематографом. Авторы рассматривают ключевые сюжеты и фигуры умолчания советской визуальной сатиры, в которой фигурируют работники системы здравоохранения, и прослеживают динамику этих сюжетов. Оптимистичная цель - выявить корни ряда современных проблем этой системы, преемницы советской, очевидных любому условно здоровому и уж тем более не очень здоровому пациенту, слишком глобальна для небольшого обзора. Тем не менее, имеет смысл проанализировать самые острые, с точки зрения карикатуристов и редакторов, проблемы советской медицины 1950-1980-х гг., дозволенные к печати и оказавшиеся в публичном дискурсе.
Основным источником исследования стала карикатура прежде всего из журнала «Крокодил». Всего было проанализировано 1419 номеров журнала, изданных с 1950 по 1991-й г. и 99 сборников серии «Мастера советской карикатуры». «Крокодил» по своей сути был не столько сатирическим, сколько идеологическим и пропагандистским изданием всесоюзного масштаба, поэтому подобные изображения можно с полным основанием считать не выходящими за рамки дозволенного.

\section{Вредители-отравители}

К началу исследуемого периода (январь 1953 г.) относится инспирированное высшим партийным руководством для нейтрализации социального протеста и широко освещаемое «дело врачей». Увенчав широкомасштабную антисемитскую истерию, «дело врачей» сломало множество жизней и работников здравоохранения, и пациентов, которые, поддавшись психозу, отказывались принимать лекарства и лечиться у врачей с еврейскими или нерусскими фамилиями [2, с. 341]. Граждане присылали в редакции газет ритуальные проклятия и требования жестоких наказаний для сетей «врачей-убийц» «в других уголках страны», требовали усилить бдительность и «почистить этих людишек», «убрать всех евреев с работы пищевого блока, торговой сети, со снабженческих работ и направить всех евреев на добычу угля» $[28$, с. 186-187].

Подлинным визиотипом «дела врачей», без которого не обходится ни одна публикация о его обстоятельствах [24], стала знаменитая карикатура Кукрыниксов «Следы преступления», размещенная на задней стороне обложки выпуска №3, от 30 января 1953 г. «Opганами Государственной безопасности раскрыта террористическая группа врачей - вредителей, наемников и агентов иностранных разведок», - гласит сопроводительный текст. 
На темно-синем сумрачном фоне, подчеркивающем драматичность происходящего, могучая рука держит за шиворот отталкивающего толстяка в хорошо пошитом коричневом костюме под белым халатом. В процессе задержания с него слетела маска «доброго доктора» - бородка клинышком, круглые очки, ласковая улыбка, медицинская шапочка. Под ней таился злобный оскал, загнутый крючком нос и хищные острые уши «вредителя», шпионский статус которого подтверждают солнечные очки и падающие золотые монеты со знаком доллара. Скрюченные пальцы «террориста» в крови. Издалека на задержание с некоторым недоумением взирают агенты английской и американской разведки все, как один, в темных очках.

Редакционная статья, опубликованная в том же номере журнала и озаглавленная «Иудиной шайке нанесен сокрушительный удар», прозрачно намекала на национальность «врагов» $\left(03 / 1953^{1}\right.$, с. 2$)$. При этом «символом советского патриотизма, высокой бдительности, непримиримой, мужественной борьбы с врагами нашей Родины» - «трижды проклятыми врачами-убийцами» «Правдой» была сделана кардиолог Лидия Тимашук, донос которой о неправильном лечении в 1948 г. члена Политбюро ЦК ВКП(б) А.А. Жданова был в нужное время использован как повод для следствия по «делу врачей» [28, с. 184].

Долгое время после этой кампании медики чувствовали на себе настороженное, а порой и откровенно враждебное отношение.

\footnotetext{
${ }^{1}$ Здесь и далее ссылка на журнал «Крокодил» дается в формате номер/год.
}

\section{Патология vulgaris}

Разумеется, реальные, а не воображаемые успехи советской медицины (снижение коэффициента материнской и младенческой смертности, в том числе в Средней Азии и на Кавказе, по сравнению с довоенными показателями; вакцинация и внедрение санитарных норм как средство предупреждения и ликвидации наиболее опасных и распространенных заболеваний и т. д. $[1 ; 17 ; 30])$ давали законный повод для гордости. Медики в белых халатах и шапочках, часто с лобными зеркалами-рефлекторами, появляются в колоннах советских трудящихся на демонстрациях, в праздничных номерах. Ничего сатирического в этих изображениях нет, это любимые «Крокодилом» многолюдные и многоцветные композиции, своего рода зеркальные витрины советской повседневности - не той, которая есть, а той, которая должна быть.

Однако в случае с визуальными образами медиков следует учитывать несколько ключевых факторов. Конечно, медиков, как и ученых [15], нередко изображали в юмористическом ключе, однако главным посылом редакторов и авторов «Крокодила» и «Мастеров советской карикатуры» было не допустить клеветы на систему в целом, а напротив, воспеть ее победное шествие. Поэтому общим местом, своего рода визуальным штампом стало изображение фигуры врача как своего рода метафоры. Подобно тому как музей часто становился визуальной метафорой чего-то устаревшего и отжившего [14], образ врачей приходил на помощь, когда требовалось преодолеть некую не соответствующую советскому строю уродливую патологию, искажающую прекрасную действительность.

Рассмотрим, как именно медики попадали в официальный сатирический дискурс. Образ врача, олицетворявшего здравый смысл, профессионализм, а также 
«стабильность, благородство и служение» [21, с. 634] контрастировал с неприятными образинами подхалимов («Болезнь Оглядкина», рис. К. Елисеева, 02/1958; «Самоотверженный подхалим», рис. Б. Савкова, $15 / 1958)$; [7]; пьяниц $(18 / 1958 ; 20 / 1961 ; 35 / 1974$; 14/1988), [11]; обжор (31/1958); низкопоклонников перед западом («Диагноз: пепси-колит», рис. М. Абрамова, 23/1959); лодырей $(27 / 1959 ; 02 / 1974)$; хулиганов (33/1963); любителей подглядывать за соседями («Клинический случай», рис. К. Елисеева, 08/1960; «Кляузник на переливании крови», рис. Л. Самойлова, 13/1964). Врачи, сталкивающиеся с социальными недугами, обычно лишь констатируют их: медицина тут бессильна, а горбатого могила исправит.

Половина всех изображений медицинских работников в сатирической печати исследуемого периода связана именно с этой визуальной метафорой. В 1960-х гг. она сделала возможным появление медицинских работников на обложке журнала, что всегда говорило о сверхактуальности темы, с точки зрения ответственных редакторов. Таковы обложки №29/1960 и 05/1965. Разумеется, в этом случае актуальными были не собственно медицинские проблемы, а пороки отдельных «пациентов»: бесхозяйственность, как на рисунке «Крайнее средство» В. Горяева («-Доктор, зима на носу, нельзя ли ее как-нибудь удалить?») и пустопорожнее бахвальство в карикатуре Е. Щеглова.

\section{«Ну-с, батенька, на что жалуетесь?»}

Сатирическая иконография медика рассматриваемого периода распадается на несколько неравных, но взаимосвязанных канонических групп.

Самая крупная из них - условный «добрый доктор Айболит», тот самый, чью маску теряет «врач-вредитель». Седой пожилой доктор, с бородкой клинышком и усами, в круглых очках, белом халате и шапочке, со стетоскопом и растрепанным медицинским саквояжем, добродушный и деловитый. Этот типаж «спеца» унаследован «Крокодилом» из суровых 1920-х, вот только пенсне (24/1926, рис. Юлия Ганфа «Больной») он сменил на очки, впрочем, все такие же старомодные, в тонкой металлической оправе.

Растиражированный образ самоотверженного доктора Айболита, созданный Корнеем Чуковским и многими блестящими иллюстраторами (Владимир Конашевич [20], Лев Эппле, Юрий Могилевский, Владимир Сутеев, Виктор Чижиков), настолько полюбился детям и взрослым, что о специализации доброго доктора просто не вспоминают: Айболит стал доктором вообще, для всех и каждого. На рисунке Евгения Гурова «Добрый доктор Айболит, он под деревом сидит...» герой сказки Чуковского с грустью ждет строительства детской больницы, начатого в 1955 г. (17/1961).

Закрепил эту связь «Айболит - последняя надежда» персонаж Олега Ефремова в мюзикле «Айболит-66» (реж. Ролан Быков) с гимном советской интеллигенции «Это даже хорошо, что пока нам плохо». В массовом сознании эта связь Айболит - Гиппократ настолько устойчива и очевидна, что приводит к казусам, подобным тому, который наблюдал один из авторов этих строк в 1999 г. в Петербурге. Судмедәксперт осматривал похмельного потерпевшего с подбитым глазом, жаловавшегося на побои и заодно требовавшего «давай, вырежь чирей, чтоб два раза не вставать». Мотивировка была такой: «Ты должен, ты же клятву Айболита давал!». «Это к ветеринару», - последовал лаконичный ответ.

Порой «Айболит» теряет растительность на лице, но никак не очки: он остается все тем же опытным, «знающим» и любимым доктором, строгим, но самоотверженным. Это, например, врач в дружной компании 
ветеранов на обложке юбилейного номера 13/1965 на рисунке И. Семенова «Двадцать лет спустя». Здесь этот обаятельный седой доктор, не расстающийся со стетоскопом даже на пикнике в лесу, также явно старше всех остальных персонажей - шахтеров, художника, космонавта, хлопокороба, рыбака, кинооператора и прочих.

Еще два воплощения этого откровенно сказочного $[19$, с. 173$]$ архетипа - врач-нарколог в исполнении Петра Петровича Репнина в «Кавказской пленнице» (реж. Леонид Гайдай, 1967 г.) и акушер в исполнении Анатолия Папанова («Дети Дон Кихота», реж. Евгений Карелов, 1966 г.). Классический доктор в исполнении крокодильцев похож на типичного старенького профессора в очках и академической ермолке. Визуальной квинтэссенцией слияния этих двух персонажей стал профессор Преображенский в исполнении Евгения Евстигнеева в фильме «Собачье сердце» (реж. Владимир Бортко, 1988 г.). Этот образ просуществовал в массовой культуре до самого конца СССР - в 1991 мы видим его в исполнении Александра Лазарева в фильме «Тень» (реж. Михаил Козаков). По мнению исследователя позднесоветского кинематографа Д.П. Кузнецова, «Патерналистский кинематограф выстраивает образ врача, наделяя его личной харизмой, особой эмоциональной притягательностью» [21, с. 105].

Кривым зеркалом для «нашего» самоотверженного и бескорыстного Айболита, который «сторонится внешнего успеха», «далек от сиюминутной выгоды», «рыцаря борьбы со смертью» (Repytwjd 105), стал образ западного врача, которого интересует только толщина кошелька пациента. Платная медицина на Западе стала одной из постоянных тем для едких политических карикатур, позволяющих продемонстрировать преимущества советского строя. Визуальный канон также был задан Кукрыниксами - это злобное хищное чудовище с крючковатым носом. Его рост и габариты варьируются, однако всепоглощающая любовь к деньгам остается неизменной. Таковы медики, вышедшие из-под кисти Юлия Ганфа («Этот больной безнадежен, у него обнаружено полное отсутствие долларов», 24/1962), Евгения Шукаева (29/1963), Марка Абрамова (06/1974), Наума Лисогорского (28/1974), Бориса Ефимова [6].

Несостоятельность теории об отечественных медиках-бессребрениках ярко проявилась в 1980-е в годы системного кризиса здравоохранения. Однако существовавшая и в предшествующие десятилетия практика «подарков» врачам и персоналу лишь подтверждают максиму доктора из «Формулы любви» (реж. Марк Захаров, 1984 г.) в исполнении Леонида Броневого: «Коли доктор сыт, так и больному легче».

\section{«Мы не пижоны, мы - врачи»}

Именно так оправдывались выпускники Ленинградского мединститута перед упрекнувшим их случайным прохожим в фильме «Коллеги» (реж. Алексей Сахаров, 1962 г.) по одноименной повести Василия Аксенова Эти молодые медики новой генерации также нашли отражение в визуальном юморе «Крокодила». Именно они, молодые люди в модных очках, во все тех же белых халатах и шапочках, пришли на смену своим учителям, сталкиваясь не только с недугами, но и с хамством, трусостью, симуляцией и недоверием пациентов (13/1962; 20/1962; 21/1979), [7; 13; 19; 22; 23].

Официальная статистика сообщала, что «СССР занимает 1-е место в мире по численности врачей и обеспеченности ими населения», а к 1975 г. «численность врачей увеличилась по сравнению с 1913 в 30 раз, обеспеченность ими - в 18 раз» [17]. Кадры врачей, фармацевтов и средних медицинских работников готовились 
масштабно: «В дореволюционной России 17 медицинских факультетов университетов и медицинских институтов выпускали ежегодно 900 врачей. К 1975 число студентов-медиков возросло в 36 раз, выпуск врачей - более чем в 50 раз. Среди учащихся медицинских учебных заведений имеются представители более 100 национальностей. Создана сеть институтов и факультетов усовершенствования врачей (в 1974 было 13 институтов и 18 факультетов)». Впрочем, современные исследования ставят под сомнение диалектический переход количества в качество [34].

Профессия медика воспринималась в массовом сознании как а) престижная в силу необходимости при любом развитии событий и б) династическая, поэтому конкурс в медицинские вузы, несмотря на длительность и сложность обучения, был значительно выше среднего. Об этом можно судить и по размерам взятки за поступление на медицинские факультеты, которая во второй половине 1970-х в республиках варьировала от 9 тысяч до 25-30 тысяч рублей и уступала лишь «взносам» за поступление в Институт народного хозяйства $[12$, c. $285 ; 18$, c. 41$]$.

К середине 1970-х в каждой союзной республике были открыты не только средние медицинские учебные заведения, но и институты, и официальные источники рапортовали о том, «выпуск специалистов удовлетворяет потребности населения в медицинских кадрах» [17]. Впрочем, очевидная, особенно в республиках, проблема блата при поступлении в медвузы поднималась довольно редко. Так, из двух студентов медицинского института в № 26/1980 («- Ты как попал в институт? - По конкурсу!») учиться собирается только один, в очках и с портфелем. Другой, бородатый и длинноволосый пижон в модной джинсе, расслабленно прогуливает пары с сигаретой в руке. Он «поступил» и те- перь украшает вузовскую самодеятельность, победив на конкурсе молодых исполнителей. Студенты-медики также появляются на традиционных январских юмористических страницах из цикла «Еще одна сессия» (рис. Анатолия Елисеева и Михаила Скобелева, 01/1970).

\section{Раздевайтесь-дышите-не дышите!}

Если образ ученого в карикатуре традиционно оставался мужским [15], то в медицине все чаще условного медицинского работника представляла женщина. Это она, с короткой стрижкой и неизменных очочках, радуется повышению заработной платы работников здравоохранения вместе с румяной продавщицей, которой тоже только что повысили зарплату (рис. А. Елисеева и М. Скобелева, 21/1964). Она вместе с учителем, строителем, футболистом, поваром и железнодорожником участвует в «Крокодильском конкурсе» на рисунке Г. Огородникова $(17 / 1980)$. Ее поздравляют в тематических «женских» мартовских номерах «Крокодила» вместе с доярками, ткачихами и учительницами, в марте же пациенты-мужчины находят время, чтобы поблагодарить своего доктора (рис. Марка Вайсборда, 07 / 1979).

В 1975 году, объявленном ООН Годом женщины, много тематических материалов «для женщин» (в том числе о моде, косметике, веснушках и диетах) появилось и в журнале «Здоровье», особенно в мартовском выпуске.

Проследим количественное соотношение мужчин и женщин в профессии через призму сюжетов в «Крокодиле» и альбомах серии «Мастера советской карикатуры»: 31,5\% женщин против 68,5\% мужчин. Показательна, например, карикатура Бориса Савкова 1964 г., изображающая планерку в больнице («Кто не согласен с докладом главного врача?» [7]: на ней шестеро мужчин и одна женщина. Разумеется, главврач - тоже 
мужчина, немного индифферентный безбородый «айболит».

Еще более впечатляет гендерная диспропорция в изображении пациентов: $19 \%$ женщин против $81 \%$ мужчин. Дело тут, разумеется, не только в «двужильности» (выражение Надежды Мандельштам) советских женщин, которые живут дольше, а болеют реже, чем их соотечественники-мужчины. Метафорически изображение ситуации посещения врача, вызова скорой или происходящего в операционной все же больше касалось не собственно медицинских проблем (их для редакторов не существовало, можно было упоминать только отдельные недостатки), а уже упоминавшиеся социальные явления, «уродующие советскую действительность. Считалось, что им в большей степени подвержены мужчины. Здесь существовало одно исключение: «курортники». Среди тех, кто тщетно добивается от врача «найти болезни согласно путевкам», больше румяных и упитанных пациенток-бездельниц, нежели пациентов («Курортный сезон в разгаре...», рис. Е. Щеглова, 17/1958; рис. Е. Самойлова, 21/1961; рис. Е. Шукаева, 20/1962). Впрочем, фальшивые бюллетени как оправдание пьяным прогулам чаще берут мужчины (06/1956, 27/1959, 02/1974, 21/1974).

Важно, что женщины чаще изображаются в качестве медсестер, нежели врачей, хотя со временем их становится больше среди терапевтов и клиницистов. Впрочем, женщины-хирурги - все же редкость в визуальной сатире. Интересное исключение - работа Анатолия Елисеева, вышедшая в номере, посвященном 50-летию СССР (35/1972) «Наглядные иллюстрации к заметкам одного “специалиста-советолога” . Эта многофигурная композиция обыгрывала этнический и региональный репертуар, пытаясь развенчать популярные стереотипы западной прессы. Так, подпись «советолога»
«Среднеазиатские женщины до сих пор закрывают лица...» сопровождает иллюстрация, на которой прелестные кокетливые медсестра и девушка-хирург изображены в медицинских масках во время операции.

Женщины-фельдшеры, медсестры, работницы регистратуры, фармацевты в аптеках, участковые врачи городских поликлиник и заводских здравпунктов - те, что непосредственно сталкиваются с пациентами, чаще своих коллег-мужчин обвинялись карикатуристами в невнимании к пациентам $(08 / 1965,05 / 1979)$, халатности и равнодушии $(23 / 1962,19 / 1964,29 / 1974)$. Общее место - суровая тетка в регистратуре, заполняющая медкарту и спрашивающая у пациента: «Пол?» (22/1960). В карикатуре Н. Лисогорского «Вездеход» по теме Д. Прутно довольная «врачиха» ловко использует служебную скорую для поездок на рынок, в парикмахерскую и «ателье мод» $(18 / 1965)$.

Женщины также в болышей степени склонны к крючкотворству и бюрократии, заполняя бесчисленные бумажки, анкеты и проч. Фельетон В. Привальского «Статис эпидемический» $(20 / 1965)$ демонстрирует портрет типичного терапевта, которому некогда поднять глаза на пациента, она в силах лишь скороговоркой произнести: «Раздевайтесь-на-что-жалуетесь-дышитене-дышите!». Пародийный вариант: «Мышите - не мышите» произносит мультипликационный доктор («Месть кота Леопольда», 1975). Понятны причины такого отношения: «поликлиники и больницы для рядового населения переполнены, в очереди на прием к врачу приходится ждать часами. Врачам же в поликлиниках установлена жесткая норма времени на прием больного, причем примерно половина этого времени уходит на записи в истории болезни» [12, с. 180]. Как известно, цена подобной «бумажки» в судьбе конкретного человека была очень высока - без справки нельзя 
было устроиться на работу, поехать в дом отдыха. Михаил Восленский приводит еще один пример регулирующей функции системы здравоохранения: «Препятствия и ограничения изыскиваются порой самые нелепые. Например, вдруг поликлиники стали отказывать в выдаче медииинской справки, - а без нее «выездное дело» не считается оформленным» [12, с. 430]. Блестящее воплощение этого иконографического типажа - персонаж Лидии Смирновой из фильма «Добро пожаловать, или Посторонним вход воспрещен» (реж. Элем Климов, 1964 г.)

Мужчины же, средний и младший медицинский персонал - фельдшеры и санитары, уволакивающие на носилках очередного «пациента», - в карикатурах изображаются довольно симпатичными, доброжелательными, с мощными бицепсами и готовностью работать $[11 ; 23$; 32]. «Нянечки», моющие полы в палатах и выносящие судна, - всегда очень пожилые женщины, замученные жизнью. Визуальный штамп сексапильной медсестры в коротком халатике проник в «Крокодил» только в самом конце 1980-х $(28 / 1989)$ и развития не получил. Советская медсестра - это, скорее, мегера с громовым басом, чемпион по метанию шприцов на рисунке Олега Теслера [27]. А вот дамы-врачи, особенно в 1950-1960-х гг. нередко изображались карикатуристами-мужчинами как невероятно привлекательные изящные особы.

\section{Терапевты VS хирурги}

Что касается специализации - численный перевес в сюжетах карикатур у врачей общей практики. Это участковые терапевты, оказывающие «амбулаторно-поликлиническую помощь населению», в том числе на производстве и на селе. «Число врачебных участков в городских поселениях возросло к 1973-му по сравнению с 1965-м более чем в два раза; если в 1955-м на терапевтический участок приходилось в среднем 3,9 тыс. человек, то в 1972-м на 10 тыс. городского населения выделялось 5 должностей участковых терапевтов» [17].

За терапевтами по числу сюжетов следуют хирурги (целыми операционными бригадами), затем - работники скорой, дантисты, психиатры, окулисты, отоларингологи, санитарные врачи, кардиологи и даже романтичные рентгенологи [31]. Как уже говорилось, лобный рефлектор Симановского не может служить достоверным указанием, например, на специализацию отоларинголога, потому что карикатуристы любили изображать его в снаряжении вообее любого врача, без разбора.

Видимая врачебная специализация часто указывает на юмористическую, а не сатирическую эмоциональную окраску изображения. Так, хирурги в визуальной сатире - образ однозначно позитивный, эталон спокойствия, собранности и профессионализма, которому, впрочем, не чуждо ничто человеческое. Отсюда возникают операционные бригады, наряжающие новогоднюю елку или вскрывающие и поедающие арбуз $(35 / 1962 ; 26 / 1965)$. Обаятелен, хотя и не очень правдоподобен с профессиональной точки зрения самый известный кинохирург Советского Союза Женя Лукашин в исполнении Андрея Мягкова («Ирония судьбы», реж. Эльдар Рязанов, 1975 г.).

Множество юмористических сюжетов связано с одним из самых «страшных» врачей - дантистом $(03 / 1958$, 24/1959, 02/1961, 13/1962, 27/1964,36/1965, 17/1988, 19/1989). Смех этот сквозь слезы, так как уровень стоматологической помощи удручал, и бедные пациенты, убегающие от врача и его пыточных инструментов, вызывают скорее сочувствие, а свирепого вида стоматологи с клещами - ужас. Нередко подобные сюжеты встречались и у коллег-карикатуристов из других стран, и «Крокодил» с удовольствием их публиковал в конце 
номера. Еще одна специализация, по поводу которой за рубежом шутили явно больше и смешнее - психиатрия. Однако в массовом сознании существовали довольно четкие представления о роли психиатрии в борьбе с инакомыслием $[8 ; 16]$, поэтому карикатуристы и редакторы не рисковали лишний раз привлекать к ней внимание.

В перечне часто встречающихся на страницах журнала медицинских специальностей отсутствуют такие специалисты, как урологи, проктологи, венерологи, гинекологи. Это, разумеется, связано с табуированием тематики телесного низа, а не с тем, что в этих сферах медицинской помощи населению все обстояло безупречно. Более того, хотя советская гинекология абсолютным большинством женщин воспринималась однозначно как карательная, а роды или аборты зачастую были самым травмирующим жизненным опытом, связанным не столько с физической болью, сколько с унижениями и намеренной грубостью персонала [4, с. 342-343], эта тема ни карикатуристами, ни редакторами-мужчинами не упоминалась вовсе до конца 1980-х. Детей приносили аисты, и любимой темой для сатирических изображений были отцы-алиментщики и легкомысленные молодые мамаши, скидывающие ребенка бабушке. Первой ласточкой в этой аистиной стае можно считать иллюстрацию из №07/1989: акушерка и медсестра спокойно пьют чай и болтают у двери родильного блока, из которой выползает новорожденный со словами: «Тетеньки, я уже родился».

\section{Персоналии}

Стремление увидеть живых людей «за зримыми очертаниями пейзажа, орудий или машин, за самыми, казалось бы, сухими документами и институтами, совершенно отчужденными от тех, кто их учредил», свой- ственное истории, по Марку Блоку [5, с. 17-18], не слишком совпадало с редакционной политикой официального издания, подведомственного газете «Правда». Тем не менее в самом конце советской эпохи среди дружеских шаржей на эстрадных звезд, поэтов и киноартистов появляются портреты врачей-знаменитостей, о которых говорила вся страна, испытывающих определенное противодействие со стороны чиновников Министерства здравоохранения. Это Гавриил Илизаров (рис. Л. Насырова, 28/1988), Валентин Дикуль (04/1989), Николай Касьян (24/1989) - оба рис. Игоря Лососинова. Он же нарисовал дружеские шаржи на теле-психиатра Анатолия Кашпировского (29/1989) и сатирика Аркадия Арканова (10/1989), окончившего Первый мед.

Эти изображения во многом визуально цитируют более ранние работы. В 1963 г. «Крокодил» поздравлял художников-Кукрыниксов дружескими шаржами под рубрикой «В сатирической клинике». Анатолий Цветков изобразил Николая Александровича Соколова (22/ 1963) и Михаила Васильевича Куприянова (29/1963) в операционной в облачении хирургов, удаляющих стиляг-поганок и прочие язвы социалистического общества.

\section{Минздрав предупреждает, но...}

Время от времени на страницах «Крокодила» появлялись сюжеты, нацеленные на пропаганду здорового образа жизни. Иногда выходили даже тематические номера, например, №29 за 1974 г. вышел с подзаголовком «Крокодил дает прикурить» и был целиком посвящен антиникотиновой пропаганде. Специальные рубрики, например, «Дым коромыслом», «Под углом 40 градусов», публиковали антиникотиновые и антиалкогольные плакаты и карикатуры, хотя и самим медикам по- 
рой были свойственны те самые вредные привычки, от которых они призывали избавиться своих пациентов. Это и стайки курящих медсестриц $(29 / 1974$, 07/1989), и дымящие, как паровозы, бородатые доктора, которые «Вышли подышать» $(08 / 1974)$. Явно навеселе и два врача, в обнимку вываливающиеся из рюмочной в «санитарный день» $(17 / 1963)$. То, что пациенты явно не принимают «последнее предупреждение» Минздрава всерьез, никого не удивляло. Например, в карикатуре Евгения Гурова из №35 за 1974 год два упившихся товарища радостно смотрят на эмблему медицины: «Вася! Закуска ползет». На фоне возросшего потребления спиртосодержащих жидкостей в условиях сухого закона появилась карикатура Евгения Милутки «Минздрав предупреждает: одеколон вреден для вашего здоровья» $(14 / 1988)$.

Время шло, и медики предостерегали против злоупотребления ДДТ $(03 / 1974)$, малоподвижного образа жизни и ратовали за подсчет калорий (суточной нормой, кстати, в 1979 году считались невероятные для 2020 года 4200 ккал, 09/1979). В 1980-х гг. немало сюжетов было посвящено нитратам в овощах и фруктах (34/1988), а вот о радиационном фоне после аварии на Чернобыльской АЭС карикатур практически не было. Еще один постоянный сюжет околомедицинских карикатур и плакатов в конце 1980-х - наркомания (17/1988, $21 / 1988)$. Традиционен для медицинских атласов Нового времени [9], но совершенно макабричен для советского журнала рисунок В. Богачева (31/1988), изображающий наркоманов - Адама, Еву и даже змеяискусителя со шприцом в виде скелетов. Вишенкой на торте визуальных сюжетов о ЗОЖ стала надпись «Минздрав предупреждает» на кружевном белье роскошной девицы, промышляющей у отеля «Интурист» (рис. Л. Насырова, 18/1988).
Системные проблемы советского здравоохранения - недоступность большинству населения современных технологий и методов лечения и вследствие этого неэффективность лечения; недостаток больниц и квалифицированных кадров в районах и сельской местности, перегруженность участковых врачей и младшего персонала в больницах; бюрократизм; разрыв между теорией и практикой, ставшее притчей во языцех хамство медперсонала $[4 ; 33 ; 34]$ проявлялись в официальной карикатуре лишь изредка. Это защита диссертации на тему «Пар костей не ломит» $(14 / 1969)$; нехватка очков или лекарств [7], долгое ожидание в очередях $(31 / 1958)$. Отдельная большая тема - широкое обращение населения к знахарям и увлечение нетрадиционной медициной (23/1956; 22/1982; 29/1989), [29], которое трактовалось художниками и редакторами исключительно как результат невежества населения, а не как следствие недоверия к официальной медицине из-за ее низкой эффективности.

Если журнал говорил о том, что «плохо налажено медицинское обслуживание населения», то это происходило не повсеместно, а только в «некоторых горных районах» (рис. Д. Синицкого, 16/1960). Лишь в конце 1980-х годов появились такие темы, как повсеместный дефицит лекарств и перевязочных материалов в аптеках и больницах (рис. О Теслера, 25/1988; 13/1989; $17 / 1989)$, пришедшие в полный упадок здания клиник и поликлиник (10/1989), нехватка мест в переполненных больницах (19/1989), невозможные условия работы для врачей (21/1989), отсутствие учета пациентов (05/1988). И если вымогание мелких взяток младшим медперсоналом («Ствоей зарплатой толькодомалечиться!», $33 / 1989)$ стало темой дозволенной, то о широко распространенной практике куда более значительных взяток«подарков» за операцию [18, с. 10] все еще не говорилось. 
Возможно, дело не только в цензуре и лакировке действительности, а в ложно понятой профессиональной этике, не позволяющей медикам выносить сор из избы. Со времен «Записок врача» Викентия Вересаева, впервые познакомившего широкого читателя с медицинским делом, повелось следовать его совету: «Конечно, в луне и солнче пятна есть, - есть они и в его профессии; но если их и можно касаться, то нужно делать это ирезвычайно осторожно и келейно, чтоб в посторонних людях не поколебалось уважение к профессии и лежашим в ее основе высоким принципам... Но ведъ всякал профессия имеет дело с людъми, ее темные стороны отзываются на людях страда ниями и кровъю? Что же делать, - пусть так, но для тех желюдей еще важнее, чтобы в них прочно было доверие к столь необходимой для них профессии» [10, с. 426-427].

И все же системный кризис, в 1990-е только усугубившийся, не замечать было уже нельзя. Первый номер 1988 года вышел с обложкой, посвященной сугубо медицинской проблеме, а не метафоре, как это было раньше. На рисунке Геннадия Огородникова хирургическая бригада не может оперировать из-за отсутствия инструментов: «-Скальпель! - Обещали в третьем квартале...». В карикатуре Александра Умярова (34/1989) двое санитаров несут на носилках символ медицины - змею, обившуюся вокруг чаши. Перебинтованную, но еще живую.

\section{0}

Многие современные образцы визуального сетевого фольклора представляются прямыми или модернизированными цитатами из плакатной и юмористической графики прошлого. Медицинская маска, которой часто снабжают изображение планеты Земля, стала настоящим визиотипом пандемии, как в свое время Землю рисовали кровоточащей и перевязанной в результате войн и массовой гибели людей [26]. Женщина-медик в работе «Время идти спать» Cris Ware на обложке журнала New Yorker от 6 апреля 2020 г. желает спокойной ночи своей семье, связываясь с ней по смартфону. На ней шапочка и маска - она на ночном дежурстве в клинике, оказывающей помощь пациентам с COVID-19. Автор варшавского мурала «Не каждый герой носит плащ. Спасибо» воспользовался обратной перспективой, чтобы показать истинных героев сегодняшнего дня врачей, медсестер, фельдшеров, работников скорой, на которых снизу вверх смотрят и обычные люди от детей до стариков, и Супермен. Закрытие границ и санитарный контроль породил екатеринбургское граффити, в котором человек в военной форме держит гигантский термометр рядом с пограничным столбом. Массовое производство мемов о самоизоляции и ее последствиях (серия «Наташ! Вставай! Мы все уронили!» и т. д.) говорит о том, что юмор, как и прежде, остается одним из главных союзников медицины в борьбе с болезнью.

Все изображения являются визуальными иитатами. 


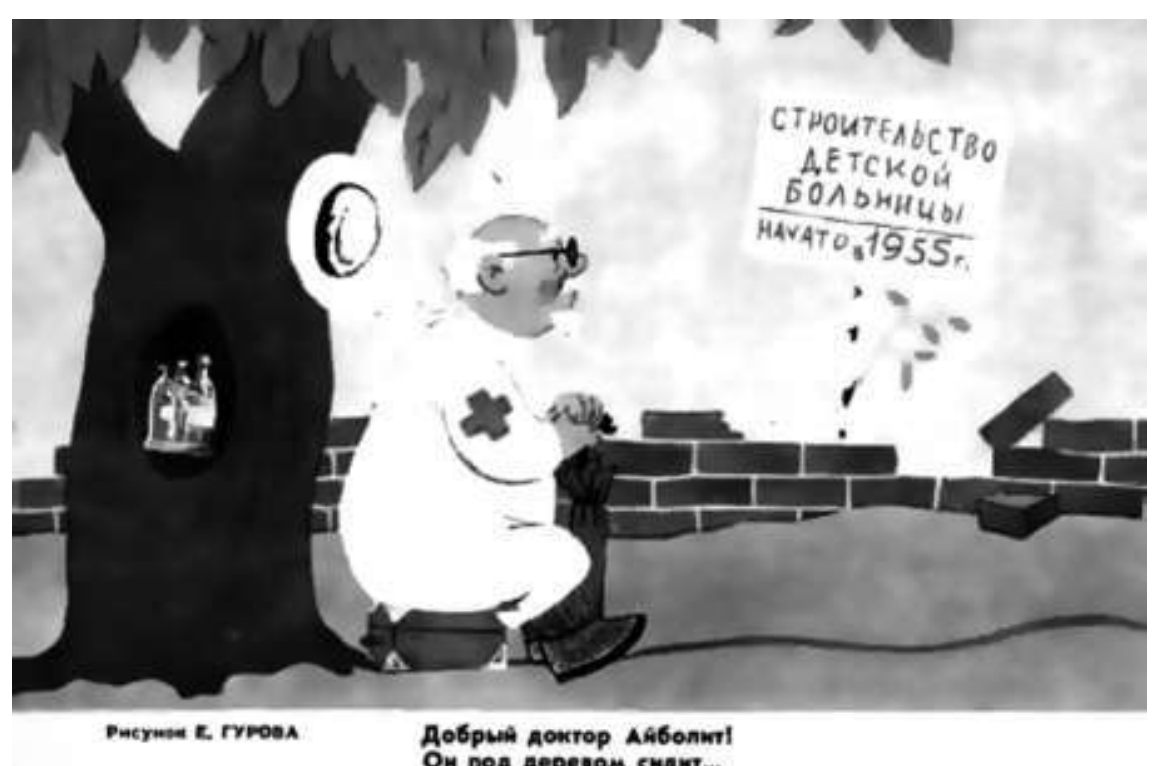

OM nOA Aepesom AM60nint

Рис. 1. «Добрый доктор Айболит, он под деревом сидит...».

Евгений Гуров («Строительство детской больницы начато в 1955 году»).

[«Крокодил», 1961, № 17]

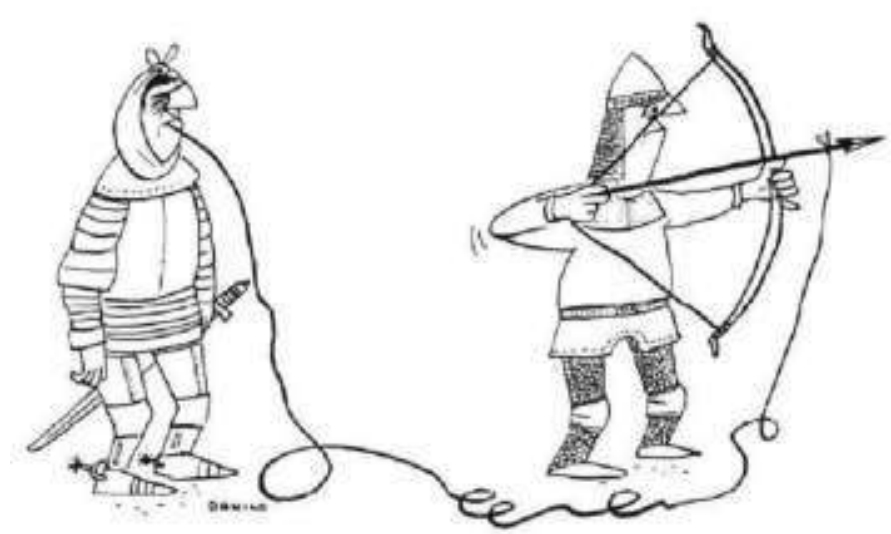

Средневековый дантмст.

Рис. 2. Средневековый дантист. Данило Аквисти (Италия) специально для «Крокодила» [«Крокодил», 1958, № 30]

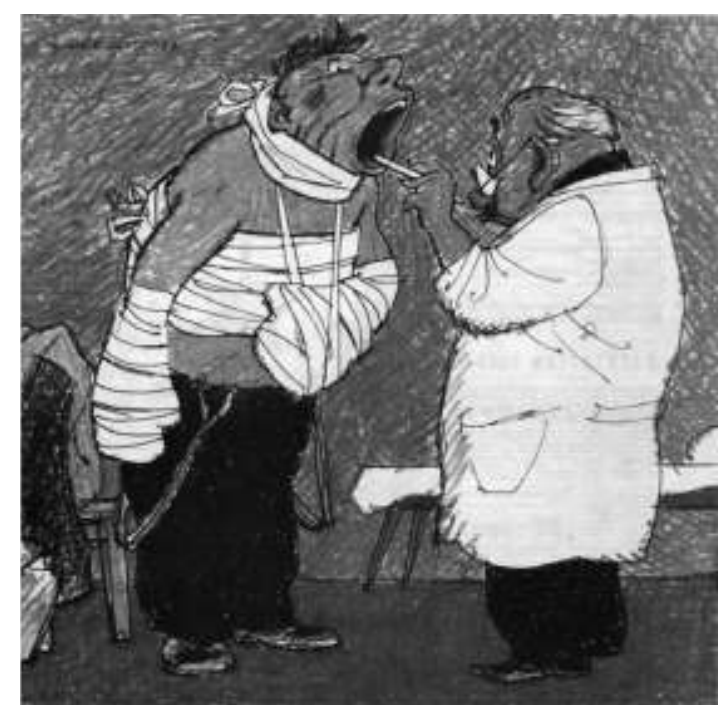

Рис. 3. « - Когда будете в следующий раз брать на себя обязательства, меньше кричите и не бейте себя в грудь!». Рисунок на обложке. Евгений Щеглов. [«Крокодил», 1965, № 05]

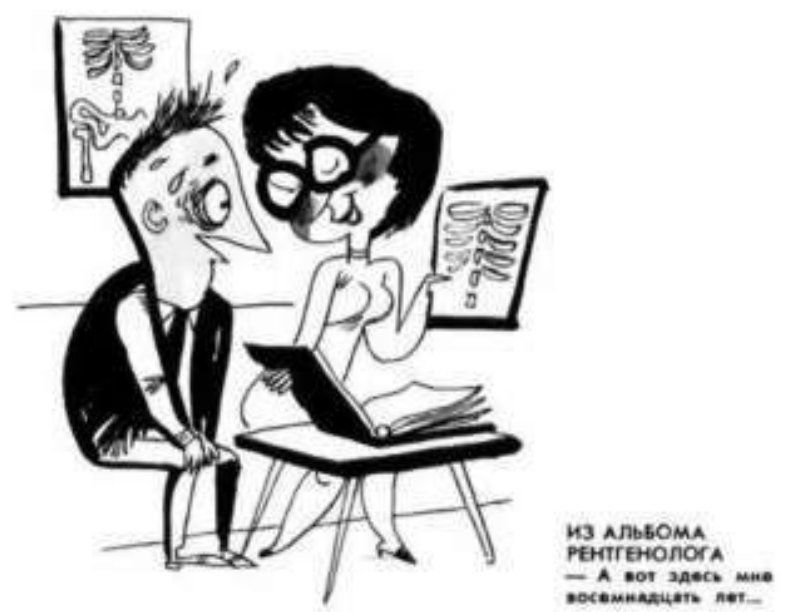

Рис. 4. Из альбома рентгенолога: « - А вот здесь мне восемнадцать лет...». Эдгар Вальтер [31] 


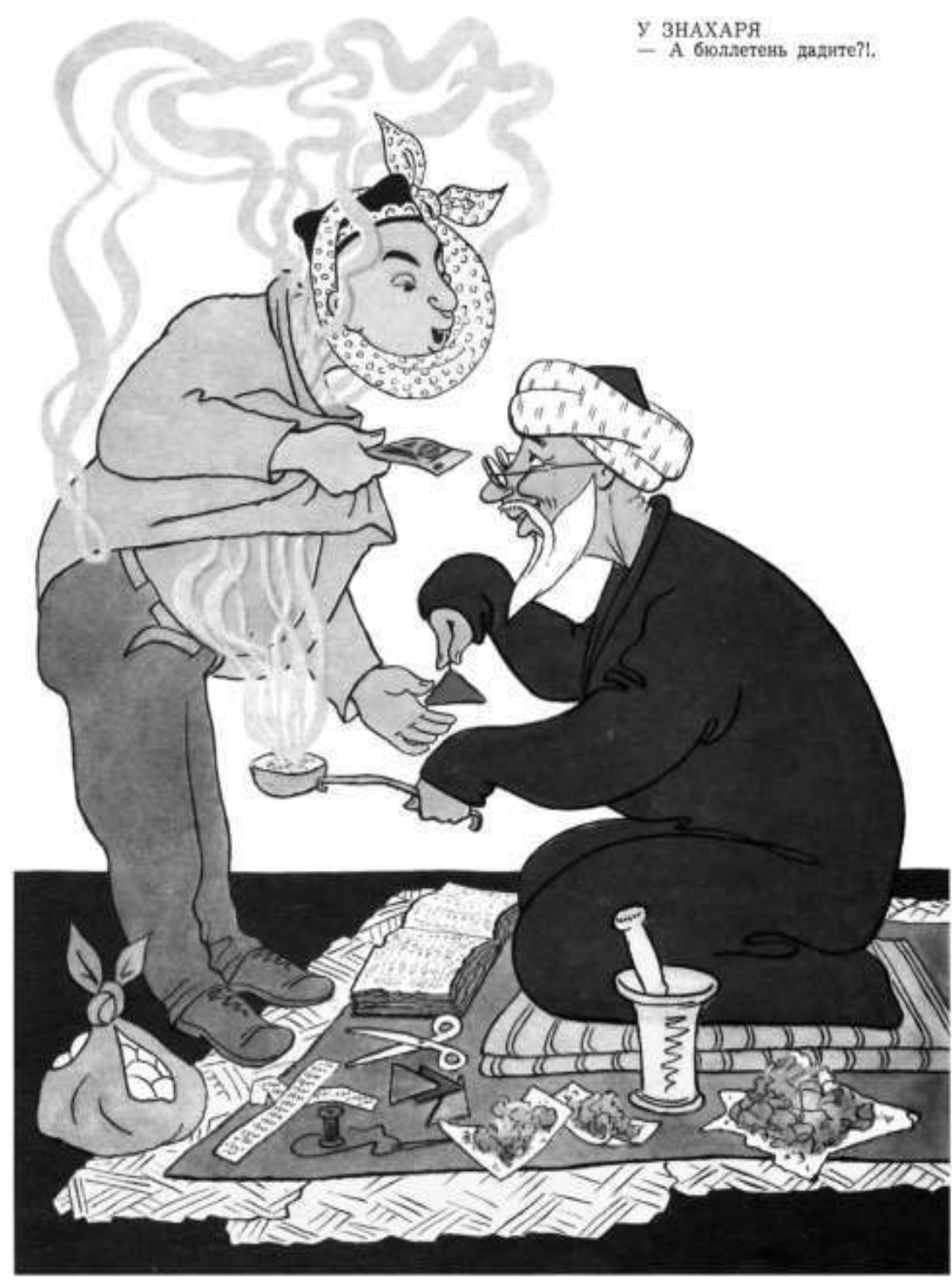

Рис. 5. У знахаря: « - А бюллетень дадите?». Хасан Расулов [29]
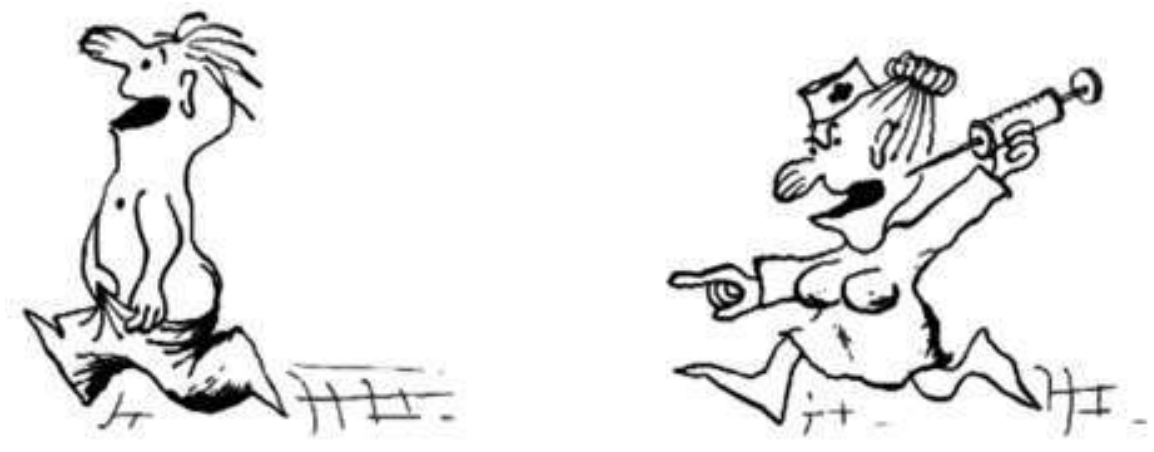

O. Tecrep. = A mocrep enopre no bec

Рис 6. «- Я мастер спорта по бегу! - А я - по метанию!». Олег Теслер [27]

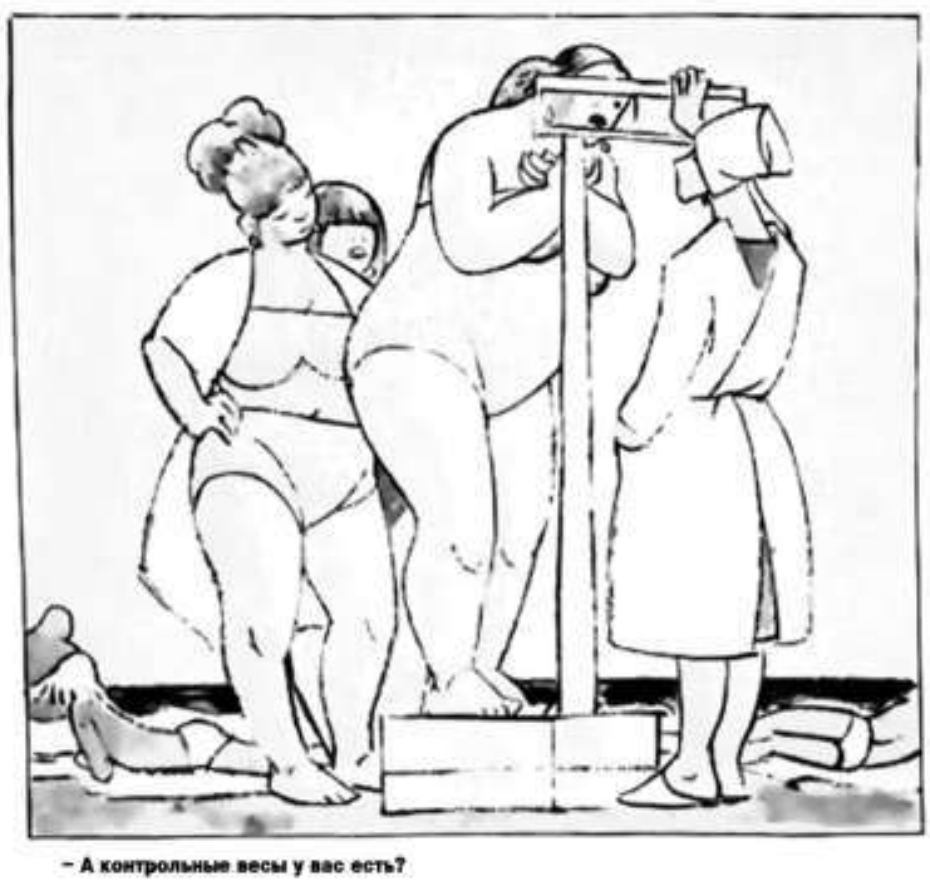

Рис. 7. «- А контрольные весы у вас есть?». Леонид Сойфертис [22] 


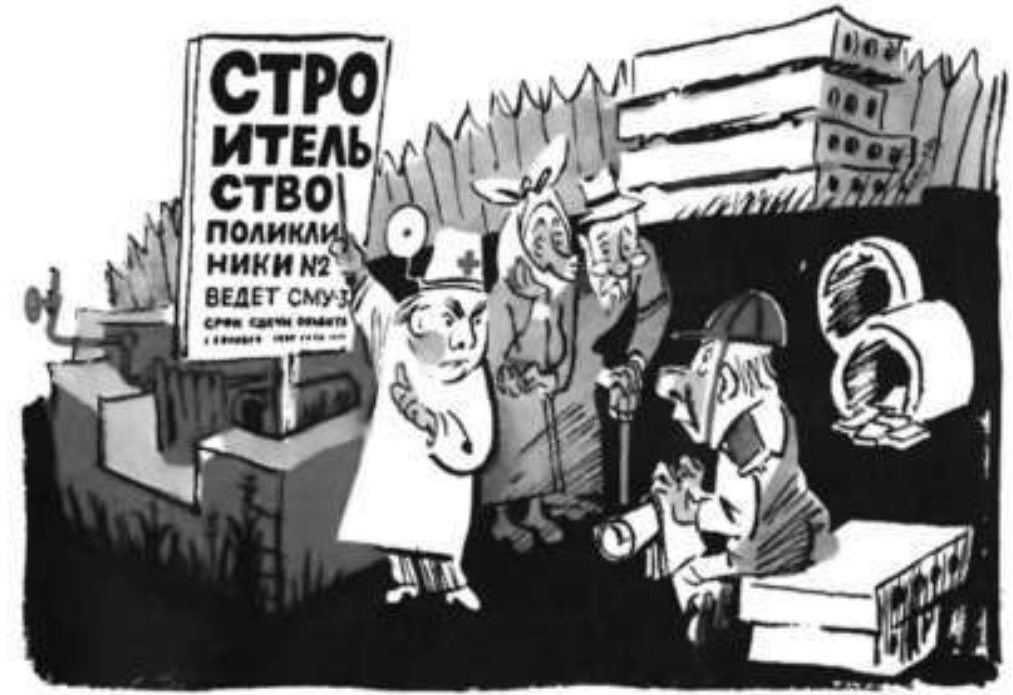

HA ПPИEME У ОКУЛИСTA

Pmсунок M. CKобелева

Рис. 8. На приеме у окулиста. («Строительство поликлиники №2 ведет СмУ-3. Дата сдачи объекта...»). Михаил Скобелев. [«Крокодил», 1980, № 34]

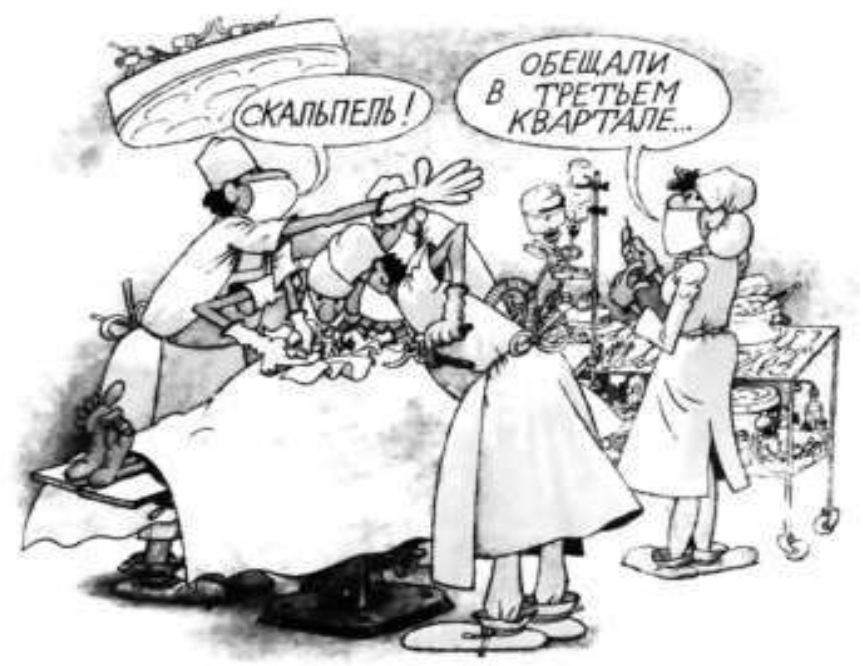

Рис. 9. «- Скальпель! - Обещали в третьем квартале...». Рисунок на обложке. Геннадий Огородников [«Крокодил», 1988, № 01]
Рис. 10. Без слов. Евгений Осипов (Ленинград). [«Крокодил», 1988, № 20]
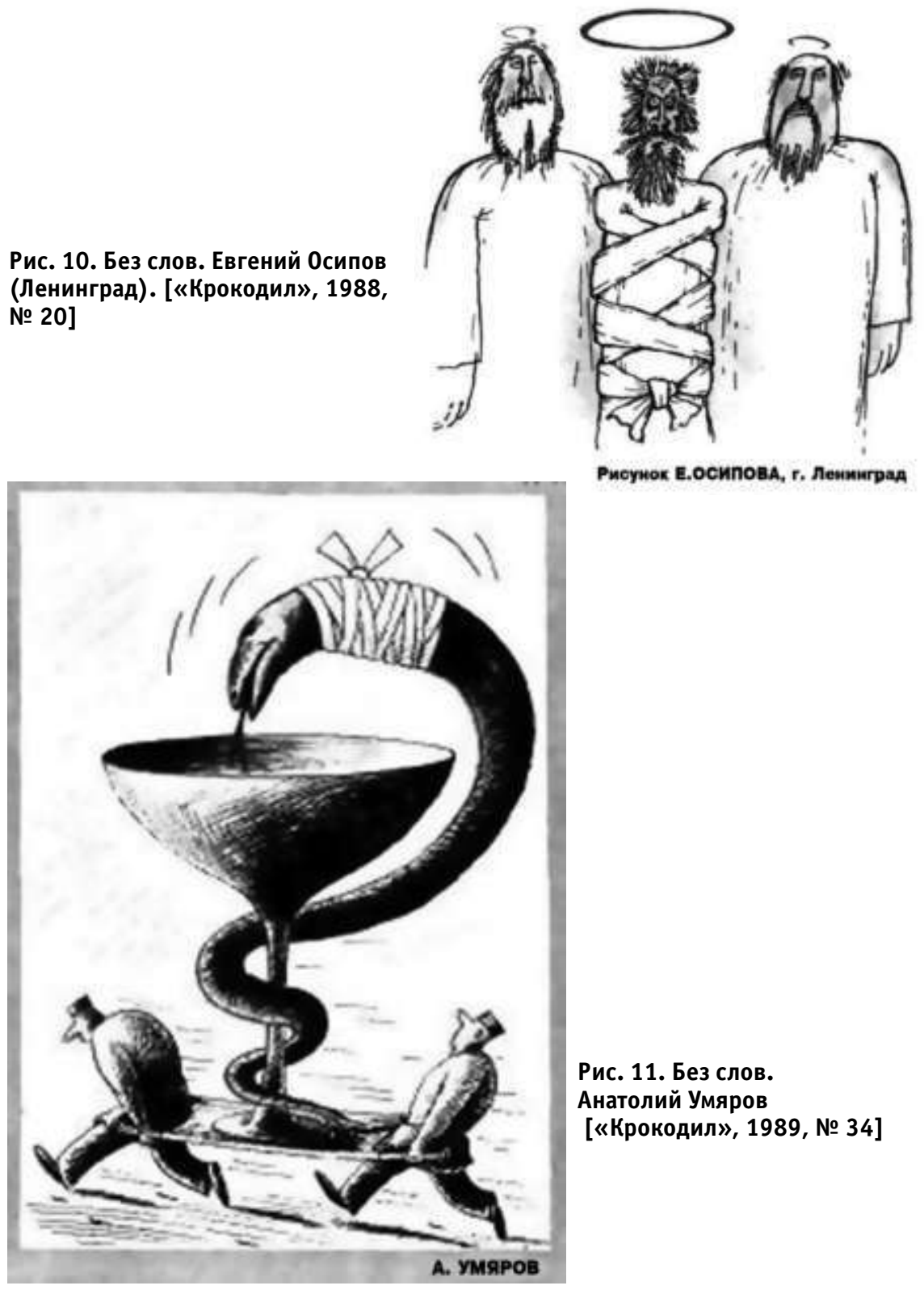

Pucynox E.осиповA, r. Лeusurpan

Рис. 11. Без слов.

Анатолий Умяров

[«Крокодил», 1989, № 34] 


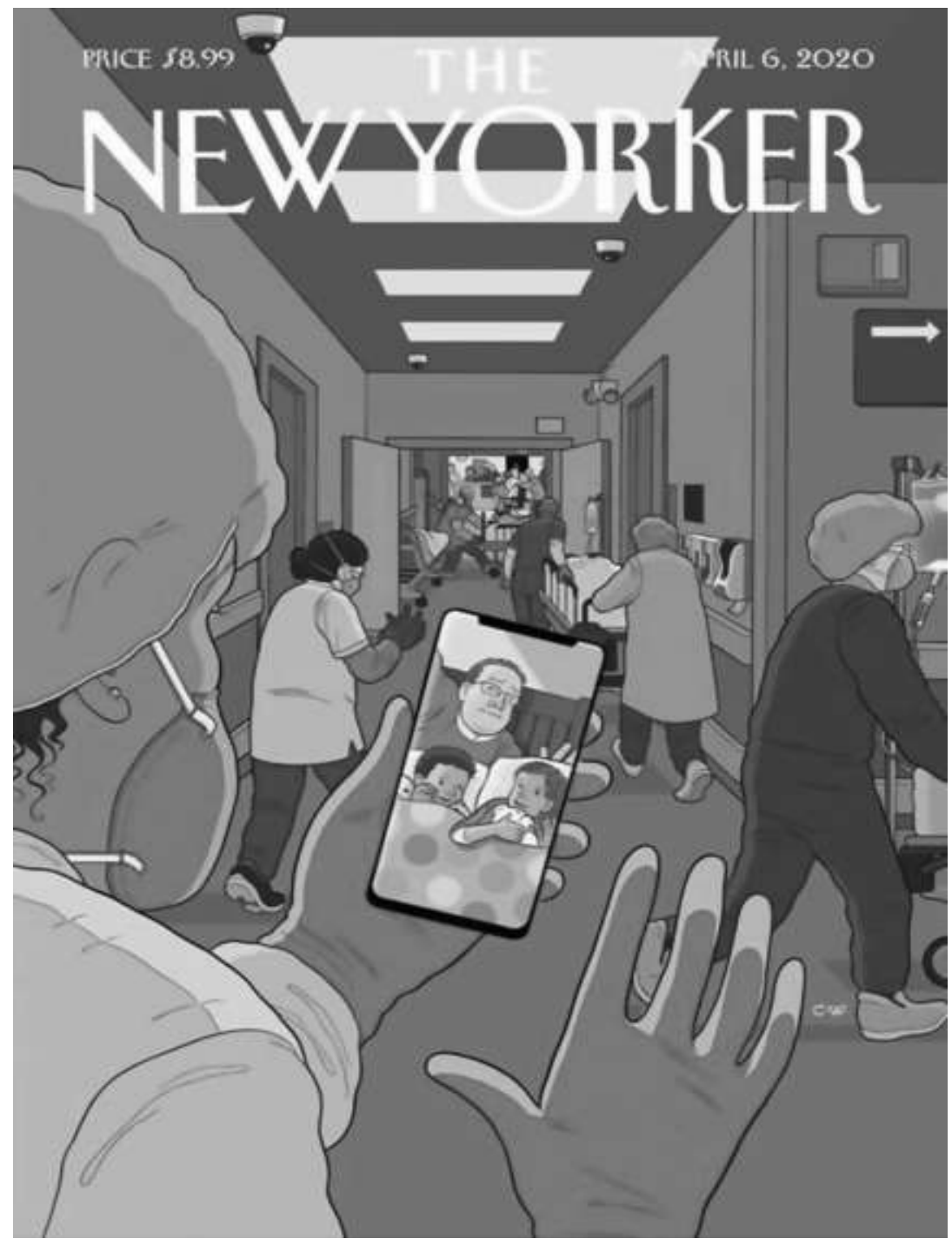

Рис. 12. Время идти спать. Крис Вейр (Cris Ware). Обложка журнала New Yorker, 6 апреля 2020. Источник: https://www.newyorker.com/

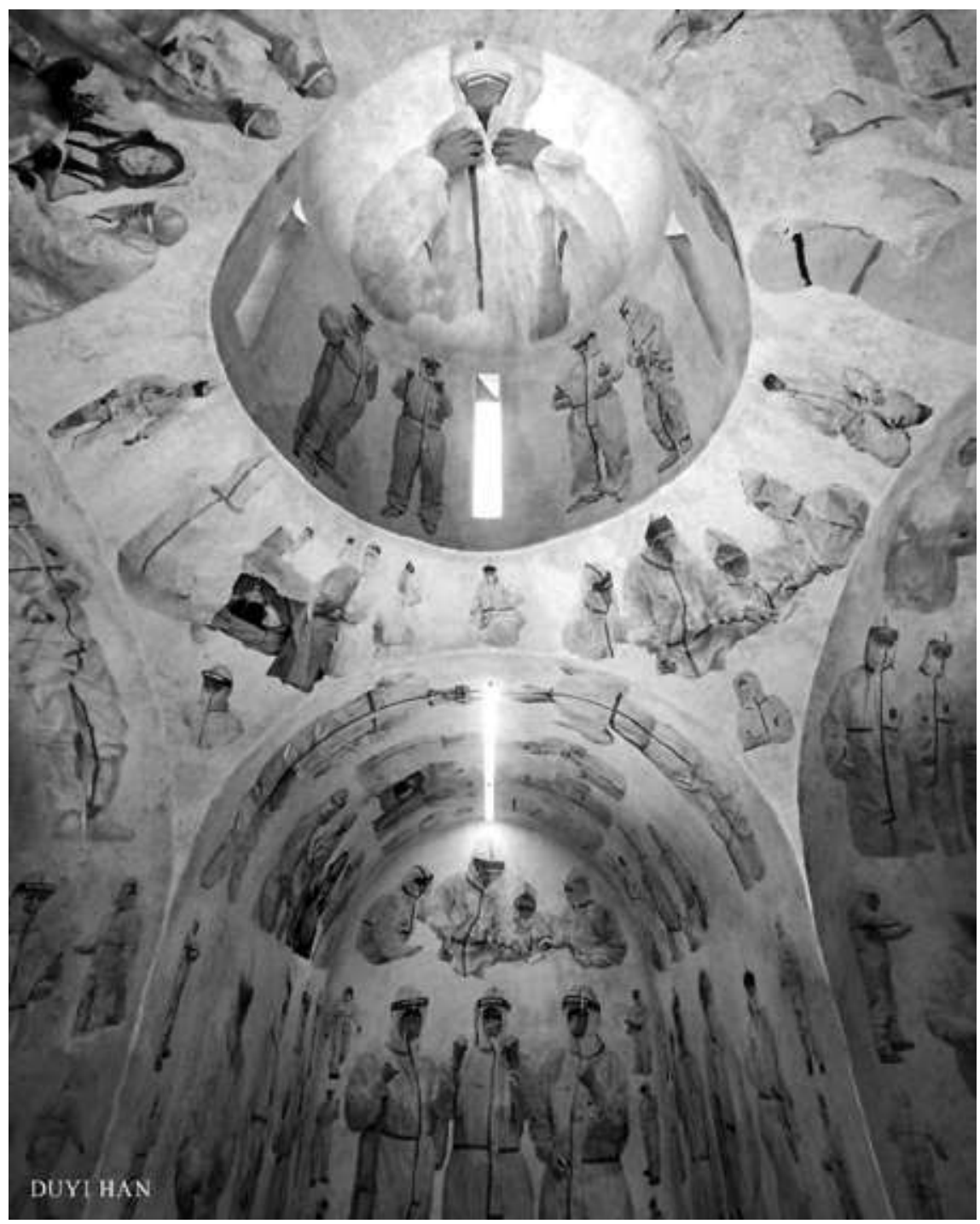

Рис. 13. Святые носят белое. Дуи Хань (КНР). 2020.

Источник: https://www.tvkultura.ru/ 


\section{Лumepamypa:}

1. 15 новых независимых государств. Коэффициент младенческой смертности 1960-2017 // Демоскоп Weekly. 2020. № 853-854, 30 марта - 12 апреля. URL: http://www.demoscope.ru/weekly/ssp/sng_imr.php (дата обращения 10.04.2020)

2. Архипова А., Кирзюк А. Опасные советские вещи: Городские легенды и страхи в СССР. М.: Новое литературное обозрение, 2020. 536 с.

3. Без слов. Мастера советской карикатуры. Выпуск 2. М.: Советский художник, 1977. Б/с.

4. Белоусова Е.А. Родильный обряд // Современный городской фольклор. М.: РГГУ, 2003. С. 339-369.

5. Блок М. Апология истории, или Ремесло историка / Пер. Е.М. Лысенко; примеч. и вступ. ст. А.Я. Гуревича. 2-е изд., доп. М.: Наука, 1986. 254 с.

6. Борис Ефимов. Из рисунков 1922-1983 гг. Мастера советской карикатуры. Альбом. М.: Советский художник, 1985. Б/с.

7. Борис Савков. Мастера советской карикатуры. Альбом. М.: Советский художник 1974. Б/с.

8. Буковский В. «И возвращается ветер...». М.: Новое издательство, 2007. 348 с.

9. Буссальи М. Тело человека: анатомия и символика / Пер. с итал. А.Г. Кавтаскина. М.: Омега, 2011. 384 с.

10. Вересаев В.В. По поводу «Записок врача» // Собр. соч.: в 4 т. М.: Правда, 1985. T. 1. C. 426-427.

11. Владимир Гальба. Карикатуры. Иллюстрации. Зарисовки. Шаржи. Альбом «Крокодила». Мастера советской карикатуры. М.: Советский художник, 1971. Б/с.

12. Восленский М.С. Номенклатура. М.: Захаров, 2015.

13. Евгений Гуров. Мастера советской карикатуры. Альбом. М.: Советский художник, 1986. Б/с.

14. Гринько И.А., Шевцова А.А. Музеи и советская сатира // Человек и культура. 2019. № 2. C. 80-96.

15. Гринько И.А., Шевцова А.А. «НИИкому не нужно»: как советских ученых видела официальная карикатура // Этнодиалоги. 2019 № 2 (58). С. 82-111.

16. Документы Инициативной группы по защите прав человека в СССР / Составители Г.В. Кузовкин, А.А. Макаров. М., 2009. URL: http://old.memo.ru/history/diss/ig/ docs/igdocs.html (дата обращения 11.04.2020)

17. Здравоохранение // Большая советская энциклопедия, 1969-1978. URL: https:// www.booksite.ru/fulltext/1/001/008/045/265.htm (дата обращения 10.04.2020)

18. Земцов И.Г. Партия или мафия? Разворованная республика. Paris: Les Éditeurs Réunis, 1976. 124 C. с. 41.

19. Зудина А.А. Наука и образ ученого в советском кино (1928-1986 годы) // 0бщественные науки и современность. 2011. № 5. С. 167-176.

20. Конашевич В.М. Воспоминания. Материалы к биографии художника. М.: Красный пароход, 2020. 352 с.

21. Кузнецов Д.П. Медицинский кинематограф позднего СССР // Научно-практический журнал. 2017. № 68. С. 101-108.

22. Леонид Сойфертис. Мастера советской карикатуры. Альбом. М.: Советский художник, 1981. Б/с.
23. Муртаз Абашидзе. Мастера советской карикатуры. Альбом. М.: Советский художник, 1989. Б/с

24. Никитин Н.В., Мухин К.Ю. Дело врачей: начало и конец // Русский журнал детской неврологии. 2010. Т. V; вып. 2. С. 53-58.

25. Савушкина Л.В., Грузнова И.В. Этический портрет врача в произведениях В.В. Вересаева и M.А. Булгакова // XLVI Огарёвские чтения: Материалы научной конференции (Саранск, 06-13 декабря 2017 г.). В 3-х частях. Отв. за вып. П.В. Сенин. Саранск: Национальный исследовательский Мордовский государственный университет им. Н.П. Огарёва, 2018. С. 630-634.

26. Сатирики мира в борьбе против империализма. Вып. 3. Мастера мировой сатирической графики. Альбом. М.: Советский художник, 1988. 80 с.

27. Сатирики о спорте. Мастера советской карикатуры. Альбом. М.: Советский художник, 1976. Б/с.

28. Фатеев А.В. Образ врага в советской пропаганде. 1945-1954 гг. Монография / Отв. ред. Петрова Н.К.; М.: Ин-т рос. истории РАН, 1999.

29. Хасан Расулов. Карикатуры. Мастера советской карикатуры. М.: Правда, 1970.

30. Шифрин М. 100 рассказов из истории медицины. М.: Альпина Паблишер, 2019. $780 \mathrm{c}$.

31. Эдгар Вальтер. Карикатуры. М.: Издание «Крокодила», 1965. Сер. «Мастера советской карикатуры». Б/с.

32. Юмор молодых. Альбом. М.: Издание «Крокодила», 1964. Б/с.

33. Friedenberg D.S. Soviet health care system // West J Med. 1987 Aug; 147 (2). Pp. 214-217.

34. Ryan M. Doctors and the State in the Soviet Union. Palgrave MacMillan, 1990. 205 p.

\section{Anna Shevtsova,}

Doctor of History, Professor of the Department of Cultural Studies,

Moscow Pedagogical State University (MSPU)

\section{Ivan A. Grinko}

PhD in History, Head of the Department for Museum

and Tourism Development (SAIC «MOSGORTUR»)

\section{Aybolit's oath: the image of a medic in the Soviet caricature}

The article is devoted to visual representations of healthcare workers in the satire of the Soviet period. The Soviet caricature and partially cinema of the 1950-1980s serve as a source base. The authors focus on the dynamics of the plots, the gender aspect, the prestige of the profession, the problems of the healthcare system, including those that remain behind the scenes. Individual stories are analyzed in comparison with modern forms of visual culture (street art, memes, etc.) devoted to the urgent topic of combating the COVID-19 pandemic.

Keywords: Soviet history, caricature, history of medicine, healthcare, image of a medic Crocodile magazine, visualization of a disease, image of a patient 